\title{
THE SIGNIFICANCE OF BUILDING PURSUITS IN ISLAM
}

Spahic Omer
Kulliyyah of Architecture and Environmental Design

International Islamic University Malaysia

e-mail : spahico@yahoo.com

\begin{abstract}
This paper explains the significance of erecting buildings in Islam. Four themes are discussed in the paper: 1) building as a basis of civilization, 2) building as an indispensable and creditable activity, 3) the Prophet Muhammad (pbuh) and building, and 4) avoiding vices in building. The paper concludes that in Islam erecting buildings is a very important enterprise, in that such signifies the creation of a physical locus of the daily individual, family and social activities of Muslims. Thus, the existence of Islamic built environment is essential for the realization of the divine purpose on earth. The chief duty that Islamic built environment performs is the facilitation of such a realization. While writing the paper, I have tried as much as possible to draw on the original sources that deal with the theme at hand, the most important of which, certainly, are the Holy Qur'an and the authentic compilations of Prophet Muhammad's words and actions. Finally, the paper aims to enhance the awareness, both of the professionals and general readership, as to the importance of correctly conceptualizing, creating and using Islamic built environment. The approach in the paper is conceptual, rather than empirical.
\end{abstract}

Keywords: Erecting Buildings, Built Environment, Islam, Muslims, Prophet Muhammad (pbuh)

\begin{abstract}
Abstrak
Makalah ini menjelaskan pentingnya pendirian bangunan dalam Islam. Empat tema yang dibahas dalam makalah ini : 1) bangunan sebagai dasar peradaban, 2) bangunan sebagai suatu kegiatan yang sangat diperlukan, 3) Nabi Muhammad (saw) dan bangunan, dan 4) menghindari kejahatan dalam bangunan. Makalah ini menyimpulkan bahwa dalam Islam mendirikan bangunan adalah sebuah usaha yang sangat penting, seperti menandakan penciptaan lokus fisik kegiatan individu sehari-hari, keluarga dan sosial umat Islam. Dengan demikian, keberadaan lingkungan yang dibangun Islam sangat penting untuk mewujudkan tujuan Ilahi di bumi. Pemimpin bertugas memfasilitasi realisasi lingkungan binaan Islam tersebut. Pada penulisan makalah ini, penulis telah berusaha semaksimal mungkin untuk menarik pada sumber-sumber asli yang berhubungan dengan tema, yang paling penting adalah Alquran dan kompilasi otentik kata-kata dan tindakan Nabi Muhammad (Hadits). Akhirnya, makalah ini bertujuan untuk meningkatkan kesadaran, baik dari para profesional dan pembaca umum, mengenai pentingnya konseptualisasi, menciptakan dan menggunakan lingkungan yang dibangun Islam. Pendekatan dalam makalah ini adalah konseptual, bukan empiris.
\end{abstract}

Kata kunci: Pendirian Bangunan, Lingkungan binaan, Islam, Muslim, Nabi Muhammad saw

\section{Introduction}

Islam is a complete way of life. Islamic civilization, which is a natural outcome of Muslims' actualization of Islam as a code for living, is likewise a comprehensive one. Islamic civilization greatly contributed to every beneficial pursuit of men permanently leaving its notable mark on all of them. Regarding the sphere of built environment, the legacy of Islam had to be distinctive because built environment is both a framework and field for the realization of Islam as a lifestyle. Hence, even a casual observer cannot fail to be struck by the huge quantity and astounding quality of architectural masterpieces of various types that Muslims under the aegis of the Islamic outlook on life's realities have produced.

\section{Building as a Basis of Civilization}

Based on his free will, awareness and imagination, man builds edifices in various shapes and sizes and with various function patterns in order to facilitate, nurture and motivate his copious life activities. In fact, such is of the fundamental things that distinguish man from other animate creatures that share this earth with him. The existence of man cannot be imagined without the existence of a built environment. The relationship between the two is causal, man always being the cause and built environment the effect. So therefore, no phase of man's presence on earth could be imagined to be devoid of building activities, irrespective of their scale and how simple and (un)sophisticated they may have been. 
Ibn Khaldun ${ }^{1}$ rightly observed that building is a basis of civilization, and is of the most indispensable crafts which man ought to gain knowledge of: "This (architecture) is the first and oldest craft of sedentary civilization. It is the knowledge of how to go about using houses and mansions for cover and shelter. This is because man has the natural disposition to reflect upon the outcome of things. Thus, it is unavoidable that he must reflect upon how to avert the harm arising from heat and cold by using houses which have walls and roofs to intervene between him and those things on all sides. This natural disposition to think, which is the real meaning of humanity, exists among (men) in different degrees..."

Le Corbusier" also remarked: "Architecture is one of the most urgent needs of man, for the house has always been the indispensable and first tool that he has forged for himself. Man's stock of tools marks out the stages of civilization, the stone age, the bronze age, the iron age. Tools are the result of successive improvement; the effort of all generations is embodied in them. The tool is the direct and immediate expression of progress; it gives man essential assistance and essential freedom also..."

The very first man on earth, Adam, was a builder, so to speak. He built the first House of worship on earth, i.e. the al-Masjid al-Haram or Baytullah (the House of God). Having descended on earth, Adam is said to have yearned for the exaltation and praises of God by angels he had accustomed himself to in the Garden of Eden, and, thus, he desired to have a house which will resound with the prayers and praises of God on earth too. God fulfilled his wish and sent down the angel Jabra'il (Gabriel) to guide and help Adam in laying the foundations of the al-Masjid al-Haram³ . Allah says in the Qur'an: "The first House (of worship) appointed for man was that in Bakka: full of blessing and of guidance for all the worlds"4 (Alu "Imran 96).

Some even assert that God did not send Adam to earth until it was set and fully equipped to accommodate him so that he and his family will be able to smoothly and responsibly carry out their duties as vicegerents (khalifah) on earth. Due to the nature of man, which is predisposed to worship, one of the essential requirements was the existence of a House of God for worship purposes. As a result, some angels were assigned to build the al-Masjid al-Haram for Adam ${ }^{3}$.

Exactly forty years following the completion of the al-Masjid al-Haram, either Adam himself or some of his offspring were instructed to proceed to a designated location (later Jerusalem or Bayt alMaqdis) and build there the al-Masjid al-Aqsa', the second mosque on earth. According to a hadith (the Prophet's tradition) Abu Dharr is reported to have said: "I have asked the Prophet (pbuh): "Which mosque was built first on earth?" The Prophet (pbuh) answered: "The al-Masjid al-Haram." Then I asked: "And which one was built thereafter?" He said: "The al-Masjid al-Aqsa." Then I asked: "What was the interval separating the two?" The Prophet (pbuh) replied: "Forty years" 5 .

It goes without saying that the craft of building, aimed at providing a framework and support for human conscious behavior, was by no means foreign to Adam and his progeny. The first generations of humans on earth needed no substantial timeframe to evolve a basic acquaintance as to the significance and purpose of building. Fundamental building skills and techniques must have been inherent in Adam, which he later passed on to his immediate offspring. Such was the case because in contradistinction to his children and the rest of humans, Adam was not born in a conventional biological way; nor was he subjected to the conventional processes of gradual learning and attaining the state of maturity - as is the case with all humans. Rather, he was created instantly as an adult. Thus, following his creation at the hands of God, Adam had to undergo an intensive and unusual learning process in order that he becomes fully prepared to take on the demanding chore of vicegerency.

On this Allah says: "Behold, thy Lord said to the angels: "I will create a vicegerent on earth." They said: "Wilt Thou place therein one who will make mischief therein and shed blood? - Whilst we do celebrate Thy praises and glorify Thy holy (name) ?" He said: "I know what ye know not." And He taught Adam the names of all things..." (al-Baqarah 30-31)

By the words "He (God) taught Adam the names of all things" we understand that God had taught Adam the inner nature, functions and qualities of all things on earth. Because they are vital for man's both survival and civilizational progression, matters related to building are believed to have been some of the things that Adam had been taught by God. They are seen as a means, an instrument, a carrier of the spiritual. Building as a craft fulfills an honorable mission, which is in line with the mission of man on earth, yet it is part of the latter.

Adam's tenure on earth was too short to be spent on discovering those things one by one and at the hands of man alone. In the same vein, being a vicegerent on earth and father of humanity, Adam's task was too big and too exigent that no time or energy could be afforded for things that could seriously distract him from concentrating on fulfilling the main purpose of his creation. It would be illogical if one were asked to accomplish a mission, only to be compelled to spend his entire lifetime trying to come to grasp with such things as means, methods, flair and other prerequisites 
needed for the task, without really succeeding even in doing that.

As a small digression, this means that Adam was a civilized and cultured being par excellence. He was God's first prophet. Yet, he was one of God's greatest prophets (ulu al-'azm min al-rusul, the prophets of firm resolution). As such, his outlook on reality, his approaches to and ways of doing things ensured him, and such as followed him, happiness and total satisfaction in both worlds. And total and continuous happiness, stemming from such boons as security, safety, knowledge, spiritual and mental health and strength, strong morals, peaceful and meaningful interaction with space and nature - is central to every civilizational enterprise in every time and space. Should a people fall short of achieving such happiness and contentment in things they plan and do, it follows, their achievements in no way can be called a civilization and their behavior a refined culture, no matter how much their outward show and make-up were able to ostensibly suggest otherwise.

Seyyed Hossein $\mathrm{Nasr}^{6}$ rightly observed: "Traditionally speaking, the truly civilized man is one who has realized this civitas Dei within himself and gained the inner vision with which he is able to realize that the only master of this city is the Immortal Spirit within and not his rebellious ego. Without this realization, man lives in barbarism even if he invents the fanciest of gadgets."

\section{Building as an Indispensable and Creditable Activity}

Humans are not the only creatures that build. Many a creature that we classify low down the hierarchy of the animal kingdom, such as bees and ants, build elaborate structures. However, it has been suggested that it is awareness and imagination that single out humans as superior to other animals in architectural output ${ }^{7}$. While the rest of creation act on the environment instinctively with no reasoning or training - as preordained by Allah, the Creator of the universe - man does the same willingly and at his own discretion. Since his actions are preceded with thinking and rationalizing, man clearly demonstrates through acts of building - and through every other engagement of his, indeed - his philosophy of, and outlook on, life and the reality. Relationship between the two, i.e. one's outlook on life and the disposition of his acts, including building, is causal, the former always being the cause of the latter. No sooner does a paradigm shift occur in one's worldview - no matter how (in)significant - than a corresponding change accordingly ensues in the very essence and character of one's performances, thus revealing and immortalizing one's actual relationship with his self, with his peers, with other creatures and, of course, with his Creator and Lord.

Erecting buildings in Islam rests within the category of permissibility (ibahah). It remains as such, so long as something does not come about causing it to infringe some of the divinely-prescribed norms, hence renders it either recommended against (makruh) or prohibited (haram). However, if observing the objectives of the shari'ah - i.e. preservation of religion, self, mental strength, progeny and wealth - is meant foremost to be thus realized, the whole matter then turns highly praiseworthy and so correspondingly rewarding. In other words, erecting buildings becomes part of one's worship ('ibadah) whereby one duly discharges some of the duties entrusted to him as a vicegerent on earth. About this Allah the Almighty says that $\mathrm{He}$ has created both Jinns and men only that they may worship and serve $\mathrm{Him}^{4}$ (al-Dhariyat 56).

On coming to this world and on becoming a member of an intricate macro web comprising different worlds and life forms, man needed not long to understand that building as an art accounted for one of the necessary requirements for man's cultural and civilizational growth, if not for his bare survival. According to the Islamic tawhidic worldview, constructed buildings are meant not only to meet some of the necessary requirements in relation to man's existence on earth, but also to facilitate, foster and stimulate his ceaseless 'ibadah (worship) practices entrusted to him by his Lord, thus helping him to elevate his status to a dignity above other creation and honorably live up to his reputation as the steward of creation. As a result, the form, design, and function of the buildings created by the Muslims are normally inspired by Islam, are permeated with its undying spirit, and stand for the embodiment of the Islamic fundamental principles and values. Given that such buildings symbolize a bodily locus of their daily individual, family and social activities, the Islamic built environment assists greatly in making Allah's righteous servants' lives all one sweet song of praise to $\mathrm{Him}$. The built environment functions as facilities to men in executing their earthly vicegerency mission. Hence, it goes without saying that central to the Islamic view of building is the function and utility of the constructed edifices. The overall physical appearance is inferior and matters only when it comes into complete conformity with the aforementioned criterion.

When the followers of Islam create a built environment, they thus create a physical locus of the meanings, messages, injunctions and guidelines of Islam, which God has presented to men in order that their life becomes divinely inspired and regulated. Islam is a complete way of life. It is to be fully internalized and practiced by its followers at 
all levels of existence. Since the built environment is a framework for all human activities, the Islamic built environment is a framework where Islam is clearly defined and then actualized at the hands of its adherents via their daily practices that delineate their relationship with people, nature and God. The built environment thus frames, so to speak, the fundamental nature of Islam revealed to men, inasmuch as it is nigh on impossible to imagine a permanent human activity that is totally separated from the confines and influences of the built environment's realm.

In view of the fact that the Islamic built environment exists in order to satisfy the requirements of Islam, either directly or indirectly, through satisfying the life requirements of those whose lifestyles stem from and reflect the ideology, teachings and values of Islam, it is Islam that holds sway over the quintessence of the built environment of the Muslims shaping its distinctive identity. It is never the opposite; that is to say, people's selfregulating thinking patterns and building styles do not hold sway over the religion and worldview of Islam. Islamic built environment exists because of Islam; it is not the other way round.

There was no Islamic built environment prior to the arrival of Islam. Islam is a cause; the Islamic built environment is an effect. Islam is the sole source that furnishes the Islamic built environment throughout the world with both its essence and identity, regarding the indigenous geographical, climatic, social and other inherited factors and features rather as second best. Undeniably, such is the power of Islam that it presides over every act, word and thought of its adherents. Anything short of this signifies nothing but a deficiency in faith. It is thus very much appropriate to identify a built environment where the spirit of Islam is a dominant factor as Islamic. As is appropriate to do the same in relation to any aspect of the same built environment where a majority of foremost Islamic principles and teachings are observed and duly applied. Hence, and rightly so, we frequently hear about such designations as the Islamic city, the Islamic house, Islamic art and architecture, etc.

Due to all this, Alfred Frazer ${ }^{8}$ said about the fundamental nature of Islamic architecture: "The architecture of Islam is the expression of a religion and its view of the world rather than that of a particular people or political or economic system."

In the same vein, Titus Burckhardt ${ }^{9}$ also wrote that it is not surprising, nor strange, that the most outward manifestation of Islam as a religion and civilization reflects in its own fashion what is most inward in it. The same author further remarked: "If one were to reply to the question 'what is Islam?' by simply pointing to one of the masterpieces of Islamic art such as, for example, the Mosque of Cordova, or that of Ibn Tulun in Cairo, or one of the madrasahs in Samarqand....that reply, summary as it is, would be nonetheless valid, for the art of Islam expresses what its name indicates, and it does so without ambiguity"9.

Certainly, it is because of this Islamic outlook on the significance of erecting buildings for noble purposes that Imam Abu Hamid al-Ghazali asserted that in Islam having a dwelling - for an instance falls within the necessary minimum that must be sought by everyone since lack of it causes the people to be displeased with God and even sometimes to deny him $^{10}$. Thus, possessing a dwelling in Islam amounts to a necessity. Such is the case merely because of the diverse social and religious roles that the house can play, and because of the house's profound impact on society, resulting, in turn, in the house institution to be perceived as a microcosm of Islamic culture and civilization.

By asserting this, al-Ghazali apparently had in mind an Islamic dictum according to which if an obligation (wajib) cannot be performed without something the latter then becomes an obligation (wajib) as well. In this case, putting into action the message of Islam, which is Islam's ultimate objective and an incumbent duty upon every individual, can only be materialized if people possess that physical locus of the family institution, i.e. the house (home), without which the total realization of the divine purpose on earth becomes virtually impossible. In other words, possessing a dwelling is fundamental to attaining righteousness and Godconsciousness, whereas homelessness breeds faithlessness and $\sin$.

\section{The Prophet Muhammad (PBUH) and Building}

In many of his words and deeds, the Prophet Muhammad (pbuh) epitomized this pragmatic but ground-breaking Islamic approach to the subject of building. The Prophet (pbuh) was an active builder, and also a planner, especially during the early years of Islam's existence in Madinah. While migrating from Makkah to Madinah, the Prophet (pbuh) rested more or less four days in Quba' - a suburb of Madinah about three miles to the south-east - whence he then proceeded to his ultimate destination, the town of Madinah. Even though his stay accounted for a short interlude, yet the Prophet (pbuh) succeeded in establishing a mosque, "Mosque of Piety", to which he frequently came, riding or walking, during his subsequent stay in Madinah. The Prophet (pbuh) is said to have positioned first a stone on the Mosque's qiblah side followed by Abu Bakr who positioned another. Next, the people started building.

Also, on his arrival in Madinah, of the first things that the Prophet (pbuh) did was marking out and then building his Mosque - the principle Mosque 
of Madinah. While building the Prophet's Mosque, the Helpers of Madinah (Ansar) and Migrants of Makkah (Muhajirun) had to stay together. It was not until the Mosque's completion that the houses for most Migrants were erected, mostly around the Mosque. In a place earmarked for building the Prophet's Mosque there were graves of some pagans and there were some date-palm trees in it. The Prophet (pbuh) ordered that the graves of the pagans be dug out and the unleveled land be leveled and the trees be cut down - the cut date-palm trees were later aligned towards the qiblah of the mosque. ${ }^{5}$ When completed, the Mosque served as both a religious and community center with activities of various types being conducted under its roof as well as in its immediate vicinity.

The Prophet (pbuh) furthermore encouraged that other mosques mushroom in different parts and suburbs of Madinah - as well as wherever Islam was embraced - so as to intensify and enhance the process of spiritual transformation and development that the people were subjected to ${ }^{11}$. He even consented to the idea of his companions earmarking places of worship ('ibadah) in their private houses. $\mathrm{He}$ is said to have graced some of such places by personally praying in them ${ }^{12}$.

Due to the prominent role and position of the mosque institution in the life of the Muslims, the Prophet (pbuh) once said that whosoever builds for the sake of God and His religion a mosque irrespective of its size - God will build for him a house in Paradise (Jannah) ${ }^{5}$. In the course of building his Mosque, the Prophet (pbuh) praised the involvement of every individual. At one point, he even assured 'Ammar b. Yasir a double reward for carrying two bricks at one time, one for himself and the other for the Prophet (pbuh), while others carried one ${ }^{13}$.

No sooner had the mosque been completed than the private houses started clustering round it under the Prophet's supervision. Due to the possible long-term impact of housing on society, the Prophet (pbuh) himself was involved in allotting and marking out many dwellings. Quite a long list of such dwellings, both their locations and owners, is supplied by some historians ${ }^{13}$. Likewise, the Prophet (pbuh) may have been involved in some way in planning and building some houses as well ${ }^{13}$. The Prophet (pbuh) has said that of man's happiness are four: a good wife, a spacious dwelling, a good neighbor, and a good mount ${ }^{14}$. He also prayed to God to forgive him, make his house more specious and bless his sustenance. Once a companion Khalid b. alWalid complained to the Prophet (pbuh) that his present house was too small to accommodate his family. At this, the Prophet (pbuh) asked him to build more rooms on the roof of the house and to ask God for abundance ${ }^{15}$.
After their migration to Madinah, the Muslims used to avail themselves of the existing markets, most of which have been controlled by the Jews. Because in these markets the blasphemous and perverse Jews perpetrated many errant practices, the Muslims gradually developed a strong aversion to doing business there. And so a new market controlled by the Muslim community was shortly set up. When selecting the site of the new market was accomplished, the Prophet (pbuh) said to the Muslims: "This is your market, it is not to be narrowed (by acquiring and building, for instance) and no tax is to be collected from it"12. The market was positioned roughly on the northwest side of the mosque, not too far from it. A number of houses stood between the market and the mosque complex. The market was approximately five hundred meters long and more than one hundred meters wide ${ }^{16}$.

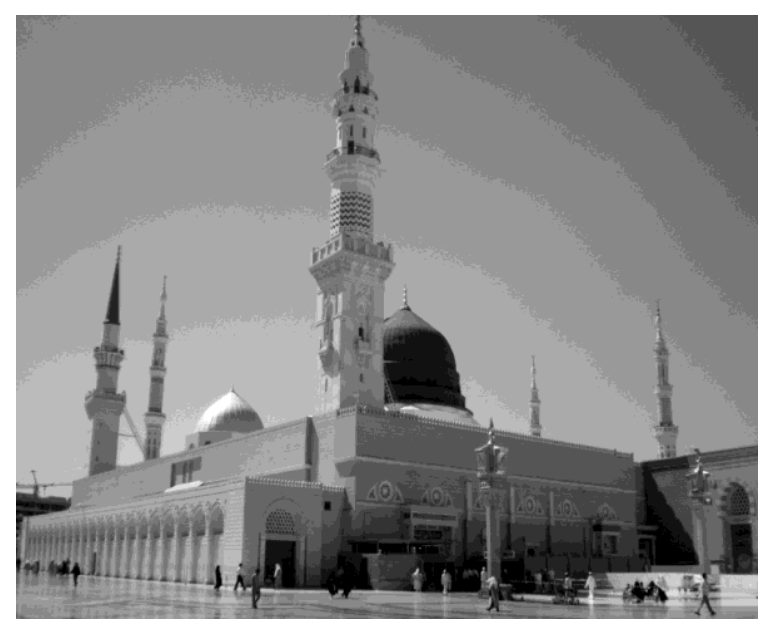

Figure 1. Prophet Muhammad's mosque in Madinah

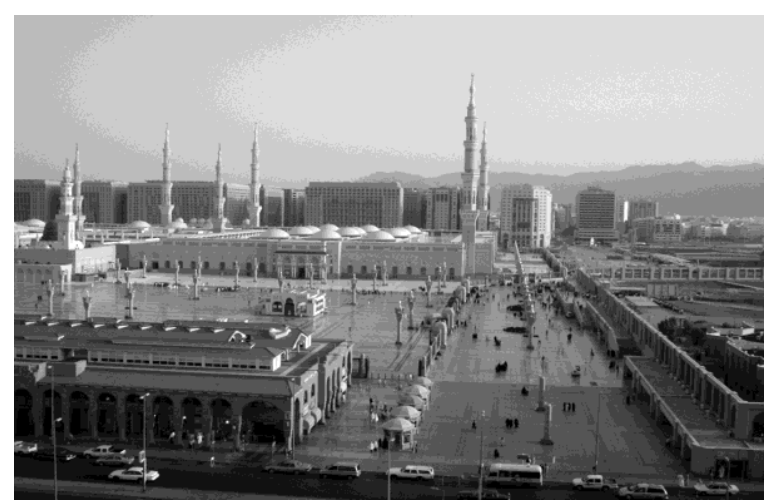

Figure 2. The Prophet's mosque today and some of its surrounding areas, seen from a nearby building. The size of today's Prophet's mosque, with all of its adjoining facilities and infrastructure, is approximately the size of what the core of the city of Madinah during the Prophet's time was.

\section{Avoiding Vices in Building}

However, one must not be so obsessed with the matter of building that some of the vices most commonly committed in building, such as wasting, 
exercising and promoting haughtiness, mutual envy and rivalry in building, may possibly be committed, even moderately. People ought to observe moderation, their limitations, personal and societal needs, and of course the utility of whatever they erect. Via its status, function and maintenance, the built environment is to be an asset to the community rather than a liability. The second caliph Umar b. alKhattab was asked by the Muslims of Kufah and Basrah - after they had built them and settled there in the wake of the conquest - to allow them to use stones rather than reeds when erecting houses, for they were more durable and less susceptible to fire and other destructive environmental factors. Because their demand was reasonable and justified, 'Umar allowed them but cautioned not to be carried away: "Do, but no one should build more than three houses. Do not vie with each other in building. Adhere to the sunnah and you will remain in power." In addition, he ordered them not to build buildings higher than was proper. Asked what "proper" was, he replied: "What does not lead you to wastefulness and does not take you away from purposeful moderation"17.

Building is but one of the noble means by which the noblest goals are attained; it is an instrument, a carrier of the spiritual, not a goal itself. People are not to build more than what they really need for the reason that every building activity will be harmful to its executor on the Day of Judgment, unless carried out due to a real necessity, i.e. to meet a need, as proclaimed by the Prophet (pbuh) ${ }^{18}$. The Prophet (pbuh) announced this on seeing a dome imposingly surmounting a house in Madinah.

The Prophet (pbuh) is also reported to have said that the most unprofitable thing that eats up the wealth of a believer is building. How true, especially if the benefits, both material and spiritual, of erected buildings are not maximized! One's wealth constitutes a major portion of what one has been assigned of this fleeting world, which is to be meticulously managed for the benefits of both worlds. Both wealth and built environment are to be perceived only as means; neither one represents an end in itself. If one possesses a positive perception about wealth and the notion of creating buildings, which, in fact, reflects one's positive total worldview, one is then able to recognize that whatever wealth he has been granted is sufficient for him. He will, furthermore, easily understand how much and what type of built environment he needs so that the execution of his divinely inspired life engagements is supported and facilitated. Hence, a believer will always be content with unassuming buildings, above all if they are private ones, thus allowing him to make use of his wealth for some other wholesome purposes, both personal and communal. This way, restraining tendencies towards the crimes of wastefulness, greed, jealousy, ill feeling, haughtiness, and so forth, in a person will become a much easier proposition. It goes without saying, therefore, that the biggest fault, as well loss, is that one exhausts all the resources and amenities that God has bestowed upon him for the momentary joy and pleasures of this world, while procuring nothing, or very little, for the Hereafter. Definitely, true believers are immune to this agonizing scenario.

If adulterated by jahiliyyah (ignorance) elements, the idea of building may in the long run prove disastrous even for the future of the Muslim community as a whole. The reason for this is that under some unfavorable circumstances not only will the issue of building and its splendid goals be then garbled, but also will people start drifting away, little by little, from purposeful moderation in the end becoming liable to warp even the character and role of their very existence on earth. No sooner does this come about than breeding the causes, which the Prophet (pbuh) has singled out as responsible for every upcoming cultural and civilizational slump of the Muslims, happens next. The causes highlighted by the Prophet (pbuh) are: exaggerated love of this world and having aversion to death ${ }^{18}$. Truly, the more people fritter away their time, energy and resources on buildings, the greater affection do they develop for the results of their work and this world in general, and the more they are attached to this world, the 'farther' and more detested death and the Hereafter appear. 'The dwellings in which you delight' has been referred to in the Qur'an (alTawbah 24) as one of the potential hindrances in Allah's cause, in that man's heart is prone to clinging to it in this world together with wealth and prosperity, commerce, and kith and kin. And if it be that any of these turns out to be a hindrance "...then wait until Allah brings about His decision: and Allah guides not the rebellious" 4 .

Against the background of these damaging vices often committed in the field of building - sometimes unconsciously and under the influence of popular and widespread dissolute trends, though - must we view every tradition of the Prophet (pbuh), as well as the sayings and practices of his nearest companions, wherein some aspects of building are at a first glance denounced.

The most conventional evil committed perhaps most often in building is wastefulness, although it is so much abhorrent that after explicitly forbidding extravagance, spendthrifts are described by the Qur'an as brothers of $\operatorname{Satan}^{4}$ (al-Isra' 27). The Prophet (pbuh) is reported to have advised his companions to enjoy this world's rightful delights so long as they are free from extravagance and conceit $^{12}$. He also said on seeing Sa'd b. Abi Waqqas taking ablution: “Why this wastefulness, O Sa'd?" Asked whether even in ablution wastefulness could be perpetrated, 
the Prophet (pbuh) retorted: "Yes, even if you are (standing) at a flowing stream"12.

Next, people's haughtiness is often a reason for building. In Islam, this vice, no matter how insignificant and for what reasons it may be committed, is unconditionally rejected. It is associated with Satan who basically for that nature of his was of those who reject Faith ${ }^{4}$ (al-Baqarah 34). The Prophet (pbuh) once said: "He in whose heart a mustard seed's weight of arrogance is found will be thrown on his face into Hellfire"14.

Also: "He who dies free from three things: arrogance, malignancy (ghulul) and debt, shall enter Paradise" 11 .

The Qur'an often refers to 'Ad, the people of the prophet Hud, in order to teach us some valuable lessons regarding building, in particular, and dealing with this world, in general. 'Ad are said to have been materialists feeling quite secure in their fortresses and resources, and believing but in brute force when dealing with those who came within their power. They were accused, among other things, of excessively priding themselves on show and parade, building palatial monuments on every high place in order to amuse themselves and impel others to hold them and their material prosperity in awe and utmost respect ${ }^{4}$ (al-Shu'ara' 123-140). When the prophet Hud came to them with Allah's message and clear signs, they ridiculed and rebuffed them, so God destroyed them by a furious wind, exceedingly violent.

Finally, as a consequence of this approach by many an individual to the subject of building, whereby a propensity to show off and display haughtiness is harbored, the tendency towards vying with each other in erecting private monumental edifices inevitably ensues. So damaging is this evil that it easily turns into a pervasive social disease. Moreover, if aided by other similar in power and effect factors, such as greed, self-centeredness, corruption, fraudulence, dishonesty, and so forth, it has a potential to evolve so far as to become an integral part of the boundless chaos that will herald the imminence of the Day of Judgment. Thus, the Prophet (pbuh) has proclaimed that one of the signs of the approaching of the Day of Judgment would be when people start vying in boasting with one another in erecting buildings ${ }^{5}$.

When a delegation from the al-Azd tribe came to the Prophet (pbuh), he advised them among other things not to build that which they will not occupy (utilize), and not to compete in that which they soon will leave ${ }^{19}$.

Nevertheless, before rivalry in building, coupled with other grave transgressions, becomes a lucid sign of the Day of Judgment's proximity, the same vice will represent one of the root causes of disunity, decadence and intellectual impotence of the Muslims, exactly as their Lord has cautioned them against: "And obey Allah and His Messenger; and fall into no disputes, lest ye lose heart and your power depart; and be patient and persevering: for Allah is with those who patiently persevere"4(alAnfal 46).

Lastly, protecting and peacefully coexisting with the natural environment while creating a built environment is paramount in Islam. Inflicting harm on the environment is a sin whose severity corresponds to the harm caused. So significant is man's relationship with the environment in Islam that in some instances such a relationship can take precedence over other deeds of man, placing him then on the highest or dragging him to the lowest. This is so because according to Islam, man is a vicegerent on earth, or steward, or manager of creation. The environment is part of God's creation too. Its role is two-fold: to worship its Creator (in ways suitable to it) and to be of service to man, so that man can smoothly and undeterred carry out his honorable task of vicegerency.

Man's rights over the environment are rights of sustainable use based on moderation, balance and conservation. The rights of the environment over man, on the other hand, are that it be safe from every misuse, mistreatment and destruction. Greed, extravagance and waste are considered a tyranny against nature and a transgression of those rights ${ }^{20}$.

Islam teaches, furthermore, that nature's resources and forces are gifts granted by God to man. "The gift, however, is not transfer of title. Man is permitted to use the gift for the given purpose, but the owner is and always remains Almighty God" 21 .

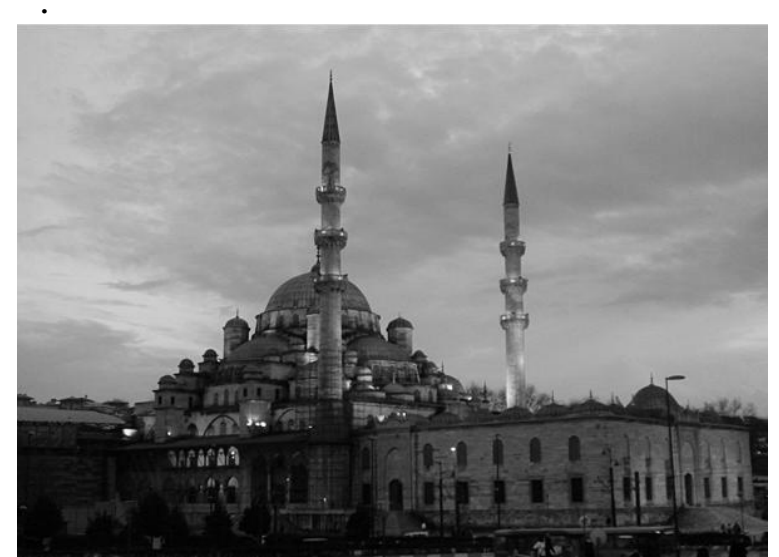

Figure 3. The Eminonu Yeni Mosque in Istanbul, Turkey 


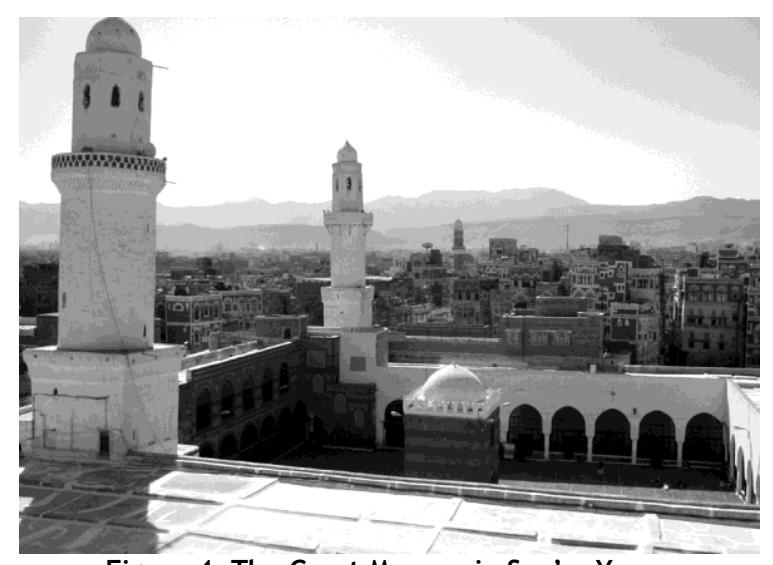

Figure 4. The Great Mosque in San'a, Yemen

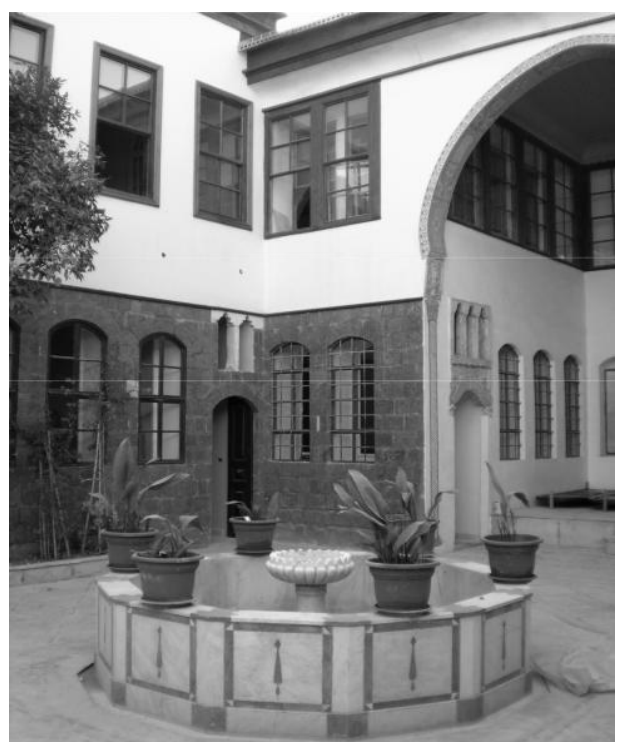

Figure 5. A courtyard house in Damascus, Syria

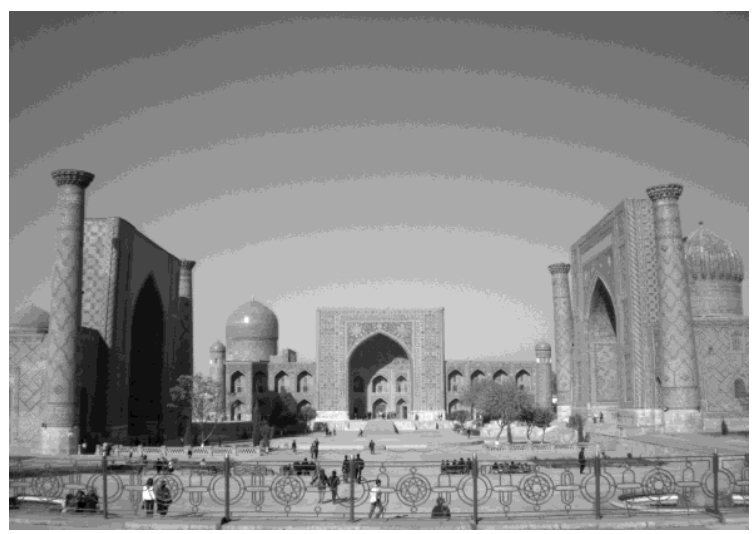

Figure 6. The Registan Square consisting of three Madrasahs (Schools) in Samarkand, Uzbekistan

\section{CONCLUSION}

Erecting buildings is a very important enterprise in Islam. It accounts for creating a physical locus of the daily individual, family and social activities of Muslims. It goes without saying that built environment, as both a concept and sensory reality, is indispensable for the fulfillment of the divine purpose on earth. However, just like any other interest of Muslims, erecting buildings likewise must be inspired by the heavenly message of Islam and its perpetual and dynamic spirit. The functions of Muslim buildings have got to mirror the interests and engagements of Muslims as God's trustees on earth. Indeed, there must always exist a high level of harmony between the two. Whenever a conflict or dichotomy between them occurs, i.e., whenever the purpose and functions of Muslim buildings become incompatible with the values and standards of Islam which Muslims are required to exemplify in their deeds, words and thoughts, that scenario spells an imminent end to the phenomenon of genuine Islamic built environment.

Due to the importance of building pursuits in Islam - as explained in the paper - Islamic architecture is perceived as a type of architecture whose functions and, to a lesser extent, form, are inspired primarily by Islam. Islamic architecture facilitates, fosters and stimulates the Muslims' 'ibadah (worship) activities, which, in turn, account for every moment of their earthly lives. Central to Islamic architecture is thus function with all of its dimensions: corporeal, cerebral and spiritual. The form divorced from function is inconsequential. This, however, by no means implies that the form plays no role in Islamic architecture. It does play a prominent role, but its relevance is a supportive one supplementing and enhancing function. The form is important, but in terms of value and substance it always plays the second fiddle to function and its wide scope.

\section{REFERENCES}

1. Ibn Khaldun (1987) The Muqaddimah. Vol. 2. Translated from the Arabic by Franz Rosenthal. London: Rotledge and Kegan Paul.

2. Le Corbusier (1989) Towards a New Architecture. Translated from the thirteenth French edition with an introduction by Frederick Etchelles. Oxford: Reed Educational and Professional Publishing Ltd.

3. Al-Azraqi (1980) Akhbar Makkah. Vol. 1. n.np. n.pp.

4. The Holy Qur'an

5. Al-Bukhari. Sahih

6. Nasr, Seyyed Hossein. Civilizational Dialogue and the Islamic World http://www.islamonline.net/english/Contempor ary.

7. Parker, Michael and Richards, Colin (1994) Ordering the World: Perceptions of Architecture, Space and Time. In Architecture \& Order. Edited by Parker Michael \& Richards Colin. London: Routledge. 
8. Fine Arts in Islamic Civilization (1981) Edited by M.A.J. Beg. Kuala Lumpur: The University of Malaya Press

9. Burckhardt. Titus. (1976) Art of Islam. London: World of Islam Festival Publishing Company Ltd.

10. Abul Quasim, Muhammad (1975) The Ethics of al-Ghazali. Kuala Lumpur: Central Printing Sendirian Berhad.

11. Al-Tirmidhi. Sunan

12. Ibn Majah. Sunan

13. Al-Samhudi (1997) Wafa' al-Wafa. Vol. 1. Beirut: Dar Ihya' al-Turath al-'Arabi

14. Ahmad b. Hanbal. Musnad.

15. 'Uthman, Muhammad 'Abd al-Sattar (1988) alMadinah al-Islamiyyah. Kuwait: 'Alam alMa'rifah.

16. Badr, 'Abd al-Basit (1993) al-Tarikh al-Shamil li al-Madinah al-Munawwarah. Vol. 1. Madinah: n.pp.

17. Al-Tabari, Ibn Jarir (1977) Tarikh al-Rusul wa alMuluk. Vol. 4. Cairo: Dar al-Ma'arif.

18. Abu Dawud. Sunan

19. Ibn Kathir (1985) al-Bidayah wa al-Nihayah. Vol. 5. Beirut: Dar al-Kutub al-'Ilmiyyah

20. Abd al-Hamid (1997) Exploring the Islamic Environmental Ethics. Ins. A. R. Aqwan (edit.). Islam and the Environmen, 39-69. New Delhi: Institute of Objective Study.

21. Al-Faruqi, Isma'il Raji (1995) Al-Tawhid: its Implications for Thought and Life. Herndon: International Institute of Islamic Thought 